\title{
Erratum to: Habitat selection by adult walleye during spawning season in irrigation reservoirs: a patch occupancy modeling approach
}

\author{
Dustin R. Martin • Larkin A. Powell • Kevin L. Pope
}

Published online: 3 May 2013

(C) Springer Science+Business Media Dordrecht 2013

Erratum to: Environ Biol Fish (2012) 93(4): 589-598

DOI 10.1007/s10641-011-9952-6

Environ Biol Fish (2013) 96(4): 429-438

DOI 10.1007/s10641-011-9939-3

This article was published twice in Volumes 93 (4) and 96 (4). Readers are advised to cite 10.1007/s10641011-9952-6 in Volume 93 (4), pp. 589 - 598.

The online version of the original article can be found at http:// dx.doi.org/10.1007/s10641-011-9952-6 and http://dx.doi.org/ 10.1007/s10641-011-9939-3.

D. R. Martin $(\bowtie)$

Nebraska Cooperative Fish and Wildlife Research Unit, and School of Natural Resources, University of Nebraska, 013 Hardin Hall, 3310 Holdrege Street,

Lincoln, NE 68583, USA

e-mail: dustin.martin@huskers.unl.edu

L. A. Powell

School of Natural Resources, University of Nebraska, 419 Hardin Hall, 3310 Holdrege Street,

Lincoln, NE 68583, USA

K. L. Pope

U.S. Geological Survey-Nebraska Cooperative Fish and Wildlife Research Unit, and School of Natural Resources, University of Nebraska,

424 Hardin Hall, 3310 Holdrege Street,

Lincoln, NE 68583, USA 